\title{
CHEMICAL AND MICROBIOLOGICAL PROPERTIES OF BROILER LITTER KEPT AT DIFFERENT ALTITUDES
}

\author{
Cahya Setya UTAMA* and Marry CHRISTIYANTO \\ Department of Animal Science, Faculty of Animal and Agricultural Sciences, Universitas Diponegoro. JI. Prof. H. Soedarto, S.H, \\ Semarang City, Central Java 50275, Indonesia \\ Email: cahyasetyautama@gmail.com; (D)ORCiD: 0000-0002-96729579 \\ Supporting Information
}

\begin{abstract}
The research objective was to assess the chemical and microbiological properties of broiler litter raised in broiler closed house at different altitudes. The design used was a completely randomized design with 3 treatments and 5 replications. The treatments consisted of T1 (broiler closed house at an altitude of $\leq 100$ meters above sea level (masl), T2 (broiler closed house at an altitude of $100-300$ masl) and T3 (broiler closed house at an altitude of $\mathbf{3 0 0}$ - $\mathbf{5 0 0}$ masl). The results showed that the difference in the altitude where broilers were raised had no significant effect on moisture, ash, extract ether (EE), crude fibre (CF), nitrogen free extract (NFE), total digestible nutrients (TDN), cuprum $(\mathrm{Cu})$, lead $(\mathrm{Pb})$, mercury $(\mathrm{Ag})$, lactic acid bacteria (LAB), Salmonella, E. coli, Clostridium sp., antibiotic contamination (below the threshold) and predominance of gram-positive bacteria. The results of water content $22.71-24.65 \%$, crude protein $13.13-13.47 \%, \mathrm{~Pb}$ 35.15-47.80 ppm, Cu 102.46-136.96 ppm, LAB 3.48 - $7.00 \times 10^{6} \mathrm{cfu} / \mathrm{g}$. In conclusion, the differences in the altitude did not affect the chemical and microbiological properties of broiler litter.
\end{abstract}

Keywords: Altitude, Bacteria, Chemical properties, Litter, Poultry.

\section{INTRODUCTION}

The increase in demand for broiler chicken meat is in line with the increase in livestock business. The increase in demand for broiler chicken meat in Central Java, Indonesia in 2019 was around 13,000 tons (Statistics of Central Java, 2019). Broiler chicken farming industry produces waste in the form of litter and can be a cause of environmental pollution (Dunlop et al., 2016; Seidavi et al., 2019). Efforts to reduce poultry waste can be done by processing the waste into materials with higher economic values (Sahoo et al., 2017).

The macroclimate and microclimate conditions of broiler house are one of the determining factors of success in the world of animal husbandry (Kic, 2016). The macroclimate and microclimate conditions of broiler house are affected by the altitude of the region where the broiler farm is built (Nazareno et al., 2016; Dróżdż et al., 2020). Extreme temperatures can be stressful for livestock and therefore affecting livestock productivity (Henry et al., 2018).

In general, the optimum temperature for the growth of broiler chickens ranges from $18-21{ }^{\circ} \mathrm{C}$, and those highland areas have lower temperatures than lowland areas (Vilchis et al., 2012). Farm management is the key to successful production of broiler chickens; one of the efforts to improve management is the use of pedestals and chicken warmers in the form of litter (Wang et al., 2016). Traditionally, the litter can be prepared from rice straw, husks, or sawdust (Garcia, 2007). The constituent composition of litter is manure, chaff and limestone. Litter contains $9-11 \%$ protein, $91-94 \%$ dry ingredients, $11-50 \%$ crude fiber and 1-3\% crude fat (Rahimi et al., 2018). Good quality litter will not be the growth medium for parasite development (Najibulloh et al., 2020). Good litter has the characteristic that the water content is 2025 percent, capable of well absorbing water, does not contain harmful materials and is dust-free (Petek et al., 2014).

The study aimed to examine the chemical and microbiological qualities of broiler litter raised in broiler closed house at different altitudes. It is expected that the study results will provide preliminary information on the quality of broiler litter obtained at different altitudes so that it can be used as the basis for the processing of litter into alternative feed materials.

\section{MATERIALS AND METHODS}

\section{Materials}

The material used was litter of 15 broiler closed house of PT. Citra Unggas Lestari located in Demak Regency (altitude $\leq 100$ meters above sea), Semarang city (altitude 100-300 meters above sea) and Kendal Regency (altitude 300-500 meters above sea level).

\section{Methods}

The research began with litter sampling of broiler chickens from 15 partnership cages PT Citra Unggas Lestari. Sampling is done purposive random sampling that can represent the percentage of area and capacity of the cage. The 
research design used is complete randomized design (CRD) with 3 treatments and 5 repeats. The treatment given is T1 (closed house cage at an altitude of $\leq 100$ meters above sea level), T2 (closed house cage at an altitude of 100-300 meters above sea level) and T3 (closed house cage at an altitude of 300-500 meters above sea level).

\section{Research parameter testing}

\section{Proximate analysis}

Proximate analysis includes testing water content, ash, crude protein, crude fat, crude fiber, calculation of extract materials without nitrogen and TDN (AOAC, 2005). Water content analysis is done using drying method with oven. Analysis of ash content is done by the method of smoking using muffle furnace (AOAC, 2005). Analysis of crude protein levels using the Kjeldahl method (AOAC, 2005). Crude Fat level analysis is done by ether extraction method (AOAC, 2005). Analysis of crude fiber levels using a method of boiling with a solution of weak acids and weak bases (AOAC, 2005). NFE levels are calculated using a formula (Alagbe et al., 2020) namely:

NFE $=100-($ Ash + Crude Fat + Crude Fiber + Crude Protein $)$

The calculation of total digestible nutrients is calculated by formula (AOAC, 2005) namely:

TDN $=\%$ Crude Fiber digestible $+\%$ NFE $+\%$ Crude Protein $+2.25 \%$ Crude Fat

\section{Metal content testing $\mathbf{P b}$}

Testing of pb metal content in the sample was done using Atomic Absorption Spectophotometer (AAS) method with different wavelength principle for each type of metal (Oliviera et al., 2017). Absorbance measured at a wavelength of 283 $\mathrm{nm}$ using AAS variant AA240 Australia and calculated the concentration of lead metal (Pb) using lead metal concentration equation $(\mathrm{Pb})$ as follows (AOAC, 2005).

$(\mu \mathrm{g} / \mathrm{g})=$ "C $\times$ VC $\times$ V" / "W W"

Description:

$C=$ concentration of $\mathrm{mg} / \mathrm{L}(\mathrm{ppm})$ measurement results converted into units of $\mu \mathrm{g} / \mathrm{L}(\mathrm{ppb})$

$\mathrm{V}=$ total sample volume $(\mathrm{mL})$ converted to liter unit $(\mathrm{L})$

$\mathrm{W}=$ sample weight $(\mathrm{g})$

\section{Cu content testing}

Testing of $\mathrm{Cu}$ content in litter samples is done by AAS method (Gu et al., 2020). The pre-prepared sample was measured with an AAS at a wavelength $(\lambda)$ of $324.8 \mathrm{~nm}$ to determine its concentration.

\section{Mercury testing}

Mercury test was conducted using qualitative and quantitative analysis of mercury using atomic absorption spectrophotometer method (Pasinszki et al., 2020). The tools used are mercury analyzer.

\section{Antibiotic contamination analysis}

Antibiotic contamination test is done using the method of screening tester bioassay (Jonkers et al., 2020). Testing using special tools such as HPLC (high pressure liquid chromatography), TLC (thin layer chromatography) and GC (Gas Chromatography) to find out the type of antibiotic compounds quantitatively (Mahmood et al., 2019).

\section{Total lactic acid bacteria analysis}

Determination of the number of total lactic acid bacteria (LAB) colonies of each litter sample is measured using the total plate count (TPC) method (Kwak et al., 2008). Colonies that grow stem-shaped, have positive grams, not form spores, are non-motile, are anaerobic, catalase negative and oxidation positive. Then the LAB population is calculated as follows:

\section{LAB Population $(\mathrm{cfu} / \mathrm{g})=$ Number of Colonies $x$ Dilution}

\section{Gram positive and negative bacterial analysis}

Testing gram positive and gram negative is done by pour method (pour plate) followed by gram staining method (gram staining method) (Rajivgandhi et al., 2018). Observations are carried out under a microscope with a magnification of $1000 x$, observed the shape of the cell and its color. If the bacteria is pink belongs to the gram negative group.

\section{Salmonella content testing}

Salmonella content testing using carter method (Andoh et al., 2017).

Escherichia Coli content testing

Identification of E. Coli content is done by Most Probable Number (MPN) method (Ahmed et al., 2015).

\section{Clostridium sp content testing}

Clostridium sp content testing is done by Total Aerobic Count method (Angelotti et al., 1961).

\section{Statistical analysis}

The data obtained was analyzed using analysis of variance (ANOVA) test to test data diversity and if there is any real influence, it will be continued with Duncan's multiple range test (DMRT) at a 5\% confidence level.

\section{Ethical approval}

The in vitro experiment did not need ethical approval from the animal ethics committee. 


\section{Proximate composition and TDN of litter from broiler chickens raised at different altitudes}

The results of the analysis indicate that the altitude of the various cage locations, namely T1 (altitude of 0-100 meters above sea level), T2 (altitude of 100-300 meters above sea level) and T3 (altitude of 300-500 meters above sea level)) did not have a real impact on the content of litter water $(P>0.05)$.In the broiler litter, the total water content was $9.2 \%$. Owen al. (2008) noted that in broiler house with a height of 120 meters above sea level, litter in the broiler chicken had a water content of 12-25\%. Qian et al. (2018) documented that broiler house at low altitudes had high temperatures that cause the chickens to consume more water so that the excreta released was moist. As the litter in all broiler houses came from the same substance, namely husks, the moisture content of the litter was not largely different. Ritz et al. (2017) stated that a suitable litter has a characteristic that the water content ranges from $20-25 \%$, able to absorb water well, does not contain harmful materials and is free from dust. The effect of altitude also does not affect the water content of litter because the type of litter source cage is the same, namely closed house cages. Closed house has a mechanism to maintain litter quality in order to remove excess moisture in the cage. This is thought to result in the litter water content produced in this study, which is not influenced by the altitude of the location. Kaukonen et al. (2016) stated that a good litter condition can be measured through the water content parameter; the optimal litter water content indicates that the litter condition is good.

The findings of the present study revealed that different altitudes of broiler house had no significant $(P>0.05)$ effects on the ash content of litter. In broiler chicken litter, the total ash content was 24.11\%. Barnes et al. (1997) reported that in broiler litter the average ash content value is $\mathbf{2 0 - 2 5}$ percent. In general, there are several factors affecting the ash content in broiler litter, which are the type of litter material as well as the altitudes of broiler house located. Pappas et al. (2010) stated that litters prepared from the materials such as wood shavings have higher absorption and have more organic content. The altitude of the location did not affect the litter ash content, presumably because there was no difference in maintenance management from each study cage. The ash content in the litter is influenced by the mineral composition of the excreta and husks, so that no differences in the mineral content have an impact on the ash content of the litter which is not different either. Owen et al. (2008) stated that the mineral content in raw materials is influenced by mineral content, because the ash content describes the amount of mineral substances that do not burn into steam.

It was shown in this study that the differences in the altitudes of location of broiler houses showed no substantial effect on the content of crude protein litter $(P>0.05)$. Crude protein content in litter has an average value of $13.31 \%$. Cross (1995) stated that the crude protein content in poultry chicken litter is $11-15 \%$. The high protein content in litter is caused by ammonia. Ferguson et al., (1998) states that the protein content in litter is still relatively high due to the presence of ammonia formed from the decomposition of nitrogen by microbes and the amount of nitrogen that is not absorbed by chickens so that it is released along with substances that are not absorbed by the body, namely excreta. This is also the reason why the elevation of the location does not affect the protein litter levels. The relatively same cage management makes no difference in ammonia in litter, so that the height of the location does not affect the litter protein content.

In this study, the altitudes of location of broiler houses had no effect on the content of Crude fiber of broiler litter ( $P>0.05)$. The average crude fiber content in broiler litter was $23.34 \%$. Stephenson et al. (1990) stated that the fiber content in poultry manure is $\mathbf{1 8 - 6 9 \%}$. The factor that causes high crude fibers in litter is the constituent component of fibers, namely lignin. Knudsen (2014) states that high fiber content is caused by lignin content as the main component of plant tissue formation. The altitude of the location does not affect the litter crude fiber content produced. The main fiber content of litter comes from rice husks, so that the fiber measured in litter is a large contribution from rice husk fiber. The cages for the source of research litter used the same base, namely rice husks, so that there was no effect of height differences on litter fiber content. The altitudes of location of broiler houses had no substantial effect on crude fat content of broiler litter. The altitude of the location does not affect the litter fat content. This can happen presumably because the litter water content is not significantly different from the location height treatment. Pappas et al. (2010) stated that the high and low levels of fat are influenced by the moisture content of the material, the amount of fat is calculated to be greater in the proximate analysis, it can occur if the water content that comes out of the material is higher. The average content of Crude fat in chicken litter was $1.72 \%$.

The results of the analysis showed that the altitude of different cage locations, namely T1 (cage altitude 0-100 meters above sea), T2 (cage altitude 100-300 meters above sea level) and T3 (altitude 300-500 meter above sea) had no real effect on the content of NFE Digestibility litter $(P>0.05)$. The absence of the influence of the location height treatment on the crude protein and crude fiber, the cause of the NFE litter value is also not affected by the location height treatment. The average content of NFE Digestibility litter chicken is 37.54. Caswell et al. (1978) stated that NFE digestibility content in chicken litter is $26.1 \%$. The value of nitrogen free extract ingredients is determined by other nutrient levels. Alam et al. (2008) stated that NFE digestibility value is influenced by the ups and downs of other levels such as crude fiber, crude protein on the material. 
The results of the analysis showed that the different altitudes of broiler house locations, namely T1 (cage altitude 0100 meters above sea), T2 (cage altitude 100-300 meters above sea) and T3 (altitude 300-500 meters above sea level) showed no real effect on the content of crude fat litter $(P>0.05)$. TDN was not different because other proximate contents such as moisture content, ash content, crude fiber, crude protein, crude fat and NFE were not affected by the altitude of the location. This results in the altitude of the location not giving different results to the TDN litter. Alam et al. (2008) stated that TDN is digestible energy derived from crude protein, crude fiber, crude fat, and NFE. The average content of chicken litter TDN was $44.86 \%$. Bagley et al. (1996) stated that the content of chicken litter TDN is $60 \%$. The TDN value of chicken litter is influenced by the fiber content of the feed. Utama et al., (2019) states that the higher the crude fiber feed, the smaller the digestibility of the feed.

\section{Contamination of $\mathrm{Pb}, \mathrm{Cu}$, Mercury and antibiotics of litter from broiler chickens raised at different altitudes}

Table 2 points to the results that the average $\mathrm{Pb}$ content in chicken litter was 42.14 ppm. Uchimiya et al. (2012) states that the average $\mathrm{Pb}$ content in the chicken litter was $38 \mathrm{ppm}$, which indicated that the level was still in normal condition. T1, T2, and T3 treatments showed no real different results. The factor that affects Pb levels in the cage is the altitudes of the cage area. Uchimiya et al. (2010) states that the use of litter in cages is determined by moisture an area, if the area has a high moisture then it can be ascertained the addition of litter so that the soil element in litter more and more.

Table 2 also shows that the average content of $\mathrm{Cu}$ in broiler chicken litter was 118.66 ppm. Codling et al. (2008) stated that in broiler chicken manure has an average content of $\mathrm{Cu}$ of $332 \mathrm{ppm}$ which is still classified as normal and when consumed ruminant livestock will not dissolve in the bloodstream and do not settle on the organs of livestock. The T1, T2 and T3 treatments showed no significant different results. The factor that affects the value of Cu is the humidity of the excreta. According to Hoeven (2014) that moisture in excreta can affect the content of Cu in broiler litter. High humidity in the high altitude can cause excreta to get wet. According to Santos et al. (2020), the height of the altitudes, which is a part of the macro environment, is related to the conditions of the broiler house microclimate. When the land level of the cage is low, the humidity in the cage is high. Environmental variables are another aspect that influences levels of $\mathrm{Cu}$. In contrast to regions with higher altitudes caused by soil elements in high areas, dissolved and settled in low areas.

Based on Table 2, that mercury content in chicken litter is low. The value of mercury in the litter of broiler chickens used ranges from 0-0.3 ppm. Malone and Chaloupka (1983) argues that mercury levels range at least 0.03-0.79 ppm, while at 0.3-0.5 ppm mercury content begins to be high. According to SNI: 7387 (2009), mercury content threshold is $0.005 \mathrm{ppm}$. Mercury levels can be overcome by some microorganisms such as pseudomonas fluorescens bacteria (Gupta and Kelly, 1992). Table 2 shows that no antibiotic residues were found in the sample chicken litter. This shows that farmers already understand the importance of discontinuing antibiotic administration and administering antibiotics according to dosage of Sun et al. (2014). According to SNI No: 01 - 6366 (2000), tetracycline antibiotic content should not exceed $0.1 \mathrm{Mg} / \mathrm{Kg}$.

Table 1 - Proximate composition and TDN litter broiler chickens kept at different altitudes.

\begin{tabular}{lccc} 
Parameters & \multicolumn{3}{c}{ Treatment (\%) } \\
\cline { 2 - 4 } & T1 & T2 & T3 \\
\hline Water content & $22.71 \pm 0.64$ & $24.65 \pm 0.80$ & $22.85 \pm 0.22$ \\
Ash content & $25.55 \pm 3.51$ & $22.79 \pm 1.36$ & $23.98 \pm 1.23$ \\
Crude protein & $13.13 \pm 1.69$ & $13.33 \pm 2.47$ & $13.47 \pm 1.16$ \\
Crude fibers & $24.31 \pm 5.28$ & $24.94 \pm 8.03$ & $20.77 \pm 1.81$ \\
Crude fat & $2.47 \pm 1.95$ & $1.28 \pm 0.81$ & $1.41 \pm 0.74$ \\
Nitrogen free extract (NFE) & $34.54 \pm 3.92$ & $37.65 \pm 6.29$ & $40.37 \pm 3.39$ \\
Total digestible nutrients (TDN) & $43.25 \pm 6.75$ & $43.76 \pm 10.02$ & $47.57 \pm 2.81$ \\
\hline
\end{tabular}

Table 2 - Content of $\mathrm{Pb}, \mathrm{Cu}$, Mercury and antibiotics of litter from broiler chickens raised at different altitudes.

\begin{tabular}{|c|c|c|c|}
\hline \multirow{2}{*}{ Parameters } & \multicolumn{3}{|c|}{ Treatment (ppm) } \\
\hline & T1 & T2 & T3 \\
\hline $\mathrm{Pb}$ & $43.49 \pm 16.67$ & $35.15 \pm 9.62$ & $47.80 \pm 19.61$ \\
\hline $\mathrm{Cu}$ & $102.46 \pm 21.03$ & $136.96 \pm 38.06$ & $116.58 \pm 24.35$ \\
\hline Mercury & 0.001 & 0.001 & 0.001 \\
\hline Antibiotics & 0.001 & 0.001 & 0.001 \\
\hline
\end{tabular}




\begin{tabular}{lccc} 
Parameters & \multicolumn{3}{c}{ Treatment (cfu/g) } \\
\cline { 2 - 4 } & T1 & T2 & T3 \\
\hline Total LAB & $7.00 \times 10^{6}$ & $3.48 \times 10^{6}$ & $5.46 \times 10^{6}$ \\
Gram + & Stem, Solitary & Stem, Solitary & Stem, Solitary \\
Gram - & Not Found & Not Found & Not Found \\
Salmonella & 0 & 0 & 0 \\
E. Coli & 0 & 0 & 0 \\
Clostridium sp & Negative & Negative & Negative \\
\hline
\end{tabular}

\section{Microbiological quality of broiler chicken litter maintained at different altitudes}

The population of lactic acid bacteria in litter is an indicator of the microbiological quality of the material. The results of the variety analysis showed that the height of different places had no real effect on the total $L A B$ litter. Total LAB observations ranged from $3.48 \times 106-7.00 \times 106 \mathrm{cfu} / \mathrm{g}$. The environment suitable for LAB life includes temperature, potential hydrogen $(\mathrm{pH})$ and nutrient content. Too high temperatures will damage the proteins that support bacterial life and cause bacteria to die (Kwak et al., 2008). Too low temperature will result in LAB dormant and not growing. Lactic acid bacteria have an optimal temperature range of $40-45^{\circ} \mathrm{C}$ and can live at pH $4-6.5$ (Adamberg et al., 2003).

The results of identification of the presence of gram-positive bacteria are rod-shaped and solitary. One type of bacteria that grows in litter is a type of gram-positive bacteria that is Lactobacillus Sp which is LAB. Lactic Acid bacteria is a bacterium that produces lactic acid that is able to inhibit the growth of gram-negative bacteria. Kwak et al., (2008) states that gram-negative bacterial permeability can be weakened by lactic acid by damaging the outer membrane of gram-negative bacteria.

Test results on litter samples showed no salmonella found results on litter. Salmonella is a type of bacteria that is pathogenic (Wiedemann et al., 2015), and according to SNI 7388 (2009) the safe limit of Salmonella content is less than 25 g. Litter may contain Salmonella derived from chicken excreta infected with Salmonella then mixed with litter. The impact of Salmonella bacterial infection on livestock can lead to Salmonellosis disease. One way to reduce salmonella content in an ingredient is by heating at a temperature of about $80^{\circ} \mathrm{C}$ (Kim et al., 2012). Investigation on the litter sample obtained no results of Escherichia coli found on the sample. E. coli are bacteria that include pathogens for humans and livestock. According to SNI 7388 (2009) the threshold of Escherichia coli infection is $10 \mathrm{~g}$. E. coli in litter comes from excreta infected with $E$. coli. The presence of $E$. coli bacteria in livestock that are often found in the gastrointestinal tract that cause colibacillosis disease will have an impact on the inhibition of nutrient absorption until the death of livestock (Hinton et al., 2000). The provision of antibacterial ingredients can inhibit the growth of E. coli. Khan et al. (2018) states that antibacterial compounds such as essential oils, triterpenoids, saponins, flavonoids, and tannins can inhibit the development of bacteria $E$. coli.

Testing the presence of Clostridium $s p$ on litter samples showed negative results in all treatments. Clostridium sp includes bacteria that are often found in livestock products and belong to the category of pathogenic bacteria (Lepp et al., 2021). According to SNI 7388 (2009) the content limit of Clostridium sp is $1 \times 10^{2}$ colonies / g. Infection from Clostridium sp can cause Clostridial Necrotizing Enteritis (CNE) disease in poultry, both diseases can result in death (Mwangi et al., 2019). Efforts can be made to inhibit the growth of Clostridium sp, namely by heating the indicated material Clostridium sp and administering vaccines to livestock.

\section{CONCLUSION}

In conclusion, the difference in the altitudes of the region does not affect the chemical quality, contamination and microbiology of litter broiler chickens that are kept at different altitudes. The chemical quality of litter that is not affected by the height of the area is moisture, ash, crude protein, crude fibre, crude fat, NFE and TDN. The Pb content in broiler chicken litter was 35.15-43.49 ppm, Cu content was 102.46-116.58 ppm, mercury content was 0.001 ppm and no antibiotic content was found. Total litter bacteria ranged from $3.48-5.46 \times 10^{6}$, gram-positive bacteria that grew on solitary and rod-shaped litter, gram-negative bacteria, bacteria, Salmonella, E. coli, Clostridium sp in broiler litter were not found.

\section{DECLARATION}

\section{Acknowledgement}

A big thank to the Institute for Research and Community Service Universitas Diponegoro for facilitating the assignment of basic research activities of the Directorate of Research and Community Service of the Directorate General of Research and Development of the Ministry of Research, Technology and Higher Education with Number: 22567/UN7.6.1/PP/2020 dated March 20, 2020.

\section{Conflict of interests}

The authors declare that they have no competing interest. 


\section{REFERENCES}

Adamberg K, Kaska S, Lahta TM, and Paalme T (2003). The effect of temperature and pH on the growth of lactic acid bacteria: a pHauxostat study. International Journal of Food Microbiology, 85(1-2): 171-183. DOI: https://doi.org/10.1016/S01681605(02)00537-8

Ahmed T, Baidya S, Acharjee, M and Rahman T (2015). Qualitative analysis of drinking water through the most probable number (MPN) method. Stamford Journal of Microbiology, 3(1): 9-16. DOI: https://doi.org/10.3329/sjm.v3i1.22745

Alagbe JO, Adeoye A and Oluwatobi AO (2020). Proximate and mineral analysis of delonix regia leaves and roots. International Journal on Integrated Education, 3(10): 144-149. Dol: https://doi.org/10.31149/ijie.v3i10.705

Alam MS, Khan MJ, Akbar MA, and Kamruzzaman MA (2008). Broiler litter and layer manure in the diet of growing bull calves. The Bangladesh Veterinarian, 25(2): 62-67. DOI: http://dx.doi.org/10.3329/bvet.v25i2.4619

Andoh LA, Ahmed S, Olsen JE, Danso KO, Newman NJ, Opintan JA, Barco L and Dalsgaard A (2017). Prevalence and characterization of Salmonella among humans in Ghana. Tropical Medicine and Health, 45: 3. DOI: https://doi.org/10.1186/s41182-017-0043-z

Angelotti R, Bailey GC, Foter MJ and Lewis KH (1961). Salmonella infantis isolated from ham in food poisoning incident. Public Health Reports, 76 (9): 771-776. https://www.ncbi.nlm.nih.gov/pmc/articles/PMC1929765/

AOAC (2005). Official Methods of Analysis. 18th Edition. Association of the Official Analytical Chemist. Washington D.C., USA

Statistics of Central Java (2019). Poultry Meat Production by Regency/Municipality and Kind of Poultry in Central Java Province. Semarang: Statistics of Central Java, Indonesia. Link

Bagley R, Evans R and Burdine, WB (1996). Broiler litter as a fertilizer or livestock feed. Journal Production Agriculture, 9(3):342-346. DOI: https://doi.org/10.2134/jpa1996.0342

Barnes KC, Smith SC, Britton JG and Miller DM (1997). Effect of poultry litter on winter weight gain of beef cows. Research Report, Beef Extention, Oklahoma State, USA. http://beef.okstate.edu/research reports/1997rr/009.htm

Caswell LF, Fontenot JP and Webb KE (1978). Fermentation and utilization of broiler litter ensiled at different moisture levels. Journal of Animal Science. 46(2): 547 -561. DOI: https://doi.org/10.2527/jas1978.462547x

Codling EE, Chaney RL, and Mulchi C L. (2008). Effects of Broiler Litter Management Practices on Phosphorus, Copper, Zinc, Manganese, and Arsenic Concentrations in Maryland Coastal Plain Soils. Communications in Soil Science and Plant Analysis. 39(7-8): 11931205. DOI: https://doi.org/10.1080/00103620801925901

Cross DL (1995). Feeding Poultry Litter to Beef Cattle. Clemson Extension Publication LL52. DOI: https://p2infohouse.org/ref/01/00096.pdf

Dróżdż D, Wystalska K, Malińska K, Grosser A, Grobelak A, and Kacprzak M (2020). Management of poultry manure in Poland - Current state and future perspectives. Journal of Environmental Management. 264: $110327 . \quad$ DOI: https://doi.org/10.1016/j.jenvman.2020.110327

Dunlop MW, Moss AF, Groves PJ, Wilkinson SJ, Stuetz RM, and Selle PH (2016). The multidimensional causal factors of 'wet litter' in chicken-meat production. Science of the Total Environment, 562: 766-776. DOI: https://doi.org/10.1016/i.scitotenv.2016.03.147

Ferguson NS, Gates RS, Taraba JL, Cantor AH, Pescatore AJ, Ford MJ and Burnham DJ (1998). The effect of dietary crude protein on growth, ammonia concentration, and litter composition in broilers. Poultry Science. 77 (10): 1481-1487. DOI: https://doi.org/10.1093/ps/77.10.1481

Garcia MC (2007). Characteristics of broiler litter using different types of materials (straw, wood shavings and rice hulls). A Castilla y Leon (Spain) case study. In International Symposium on Air Quality and Waste Management for Agriculture, Broomfield, CO. Pub (No. 701P0907cd). DOI: http://dx.doi.org/10.13031/2013.23910

Gu C, Ji Y, Zhang Y, Yang Y, Liu J and Ni T (2020). Recycling use of sulfate-rich sewage sludge ash (SR-SSA) in cement-based materials: Assessment on the basic properties, volume deformation and microstructure of SR-SSA blended cement pastes. Journal of Cleaner Production. 282: 124511. DOI: https://doi.org/10.1016/i.jclepro.2020.124511

Gupta $G$ and Kelly P (1992). Poultry litter toxicity comparison from various bioassays. Journal of Environmental Science and Health. Part A: Environmental Science and Engineering and Toxicology, 27 (4): 1083-1093. DOI: https://doi.org/10.1080/10934529209375781

Henry B, Eckard R and Beauchemin K (2018). Review: Adaptation of ruminant livestock production systems to climate changes. Animal, 12 (suppl.2): 445-456. DOI: https://doi.org/10.1017/S1751731118001301

Hinton A, Buhr RJ and Ingram KD (2000). Reduction of Salmonella in the crop of broiler chickens subjected to feed withdrawal. Poultry Science, 79(11):1566-1570. DOI: https://doi.org/10.1093/ps/79.11.1566

Hoeven EV (2014). Broiler excreta composition and its effect on wet litter. Wageningen University. (Thesis). ISBN 9789461738646. Link: https://library.wur.nl/WebQuery/wurpubs/448734

International Organization of Standardization 4833. (1991). General guide lines for the enumeration of Microorganisms-Colony count Technique at $300 \mathrm{C}$ (Second Edition). Technical committee: ISO/TC 34/SC 9 Microbiology, 12 pp. Link: https://www.iso.org/standard/10816.htm

Jonkers TJH, Steenhuis M, Schalkwijk L, Luirink J, Bald B, Houtman CJ, Kool J, Lamoree MH and Hamers T (2020). Development of a highthroughput bioassay for screening of antibiotics in aquatic environmental samples. Science of the Total Environment. 729: 139028 DOI: https://doi.org/10.1016/j.scitotenv.2020.139028

Kaukonen E, Norring $M$ and Valros A (2016). Effect of litter quality on foot pad dermatitis, hock burns and breast blisters in broiler breeders during the production period. Avian Pathology, 45(6): 667-673. DOI: https://doi.org/10.1080/03079457.2016.1197377

Khan MI, Ahhmed A, Shin JH, Baek JS, Kim MY and Kim JD (2018). Green tea seed isolated saponins exerts antibacterial effects against various strains of gram positive and gram negative bacteria, a comprehensive Study In Vitro and In Vivo. Evidence-Based Complementary and Alternative Medicine. 2018: Article ID 348610. DOI: https://doi.org/10.1155/2018/3486106

Kic P (2016). Microclimatic conditions in the poultry houses. Agronomy research, 14: 82-90. Link: https://www.cabdirect.org/cabdirect/abstract/20163195220

Kim J, Diao J, Shepherd Jr MW, Singh R, Heringa SD, Gong C and Jiang X (2012). Validating thermal inactivation of salmonella spp. In fresh and aged chicken litter. Applied and Environmental Microbiology. 78(4): 1302-1307. DOI: http://dx.doi.org/10.1128/AEM.0667111

Knudsen KEB (2014). Fiber and nonstarch polysaccharide content and variation in common crops used in broiler diets. Poultry Science, 93(9): 2380-2393. DOI: https://doi.org/10.3382/ps.2014-03902

Kwak WS, Jung SH and Kim YI (2008). Broiler litter supplementation improves storage and feed-nutritional value of sawdust-based spent mushroom substrate. Bioresource Technology. 99(8): 2947-2955. DOI: https://doi.org/10.1016/j.biortech.2007.06.021 
Lepp D, Zhou Y, Ojha S, Gohari IM, Carere J, Yang C, Prescott JF and Gong J (2021). Clostridium perfringens produces an adhesive pilus required for the pathogenesis of necrotic enteritis in poultry. Journal of Bacteriology. 203 (7): 1-14. DOI: https://doi.org/10.1128/JB $.00578-20$

Mahmood AR, Al-Haideri HH and Hassan FM (2019). Detection of antibiotics in drinking water treatment plants in Baghdad City, Iraq Advances in Public Health. 7851354: 1-11. DOI: https://doi.org/10.1155/2019/7851354

Malone GW and Chaloupka GW (1983). Composted Municipal Garbage for Broiler Litter. Poultry Science. 62(3): 414-418. DOI: https://doi.org/10.3382/ps.0620414

Mwangi S, Timmons J, Fitz-coy S and Parveen S (2019). Characterization of Clostridium perfringens recovered from broiler chicken affected by necrotic enteritis. Poultry Science. 98 (1): 128-135. DOI: https://doi.org/10.3382/ps/pey332

Najibulloh M, Ulupi N and Salundik (2019). Effect of litter recycling on litter and air quality in broiler maintenance. Livestock and Animal Research. 18 (2): 107-115. DOI: https://doi.org/10.20961/lar.v18i2.42932

Nazareno AC, Silva ID, and Fernandes DP (2016). Prediction of mean surface temperature of broiler chicks and load microclimate during transport. Engenharia Agricola. 36(4): 593-603. DOI: https://doi.org/10.1590/1809-4430-Eng.Agric.v36n4p593-603/2016

Owen OJ, Ngodigha E M and Amakiri AO (2008). Proximate composition of heat treated poultry litter (layers). International Journal of Poultry Science. 7 (11): 1033-1035. DOI: https://dx.doi.org/10.3923/ijps.2008.1033.1035

Pappas AC, Zoidis E, Theophilou N, Zervas G and Fegeros K (2010). Effects of palygorskite on broiler performance, feed technological characteristics and litter quality. Applied Clay Science. 49 (3): 276-280. Dol: https://doi.org/10.1016/j.clay.2010.06.003

Pasinszki T, Krebsz M, Chand D, Kótai L, Homonnay Z, Sajó IE and Váczi T (2020). Carbon microspheres decorated with iron sulfide nanoparticles for mercury (II) removal from water. Journal of Materials Science. 55(4): 1425-1435. DOI: https://doi.org/10.1007/s10853-019-04032-3

Petek M, Üstüner H and Yeșilbağ D (2014). Effects of stocking density and litter type on litter quality and growth performance of broiler chicken. Kafkas Universitesi Veteriner Fakultesi Dergisi. 20(5): 743-748. Article Link: http://vetdergikafkas.org/uploads/pdf/pdf_KVFD_1660.pdf

Qian X, Lee S, Chandrasekaran R, Yang Y, Caballes M, Alamu O and Chen G (2019). Electricity evaluation and emission characteristics of poultry litter co-combustion process. Applied Sciences. 9 (4116): 1-15. DOI: https://doi.org/10.3390/app9194116

Rahimi MR, Alijoo YA, Pirmohammadi R and Alimirzaei M (2018). Effects offeeding with broiler litter in pellet-form diet on qizil fattenins lambs' performance, nutrient digestibility, blood metabolites and husbandry economics. Veterinary Research Forum. 9(3): 245-251. DOI: https://dx.doi.org/10.30466/vrf.2018.32081

Rajivgandhi G, Maruthupandy M, Ramachandran G, Priyanga M and Manoharan N (2018). Detection of ESBL genes from ciprofloxacin resistant Gram negative bacteria isolated from urinary tract infections (UTIs). Frontiers in Laboratory Medicine. 2(1): 5-13. DOI: https://doi.org/10.1016/i.flm.2018.01.001

Ritz CW, Faifchild BD and Lacy MP (2017). Litter quality and broiler performance. UGA Extension Bulletin 1267, Georgia. Article link: https://secure.caes.uga.edu/extension/publications/files/pdf/B\%201267_5.PDF

Sahoo SP, Kaur D, Sethi APS, Sharma A, Chandra M and Chandrahas (2017). Effect of chemically amended litter on litter quality and broiler performance in winter. Journal of Applied Animal Research. 45(1): 533-537. DOI https://doi.org/10.1080/09712119.2016.1150846

Santos VM, Dallago BSL, Racanicci AMC, Santana AP, Cue RI and Bernal FEM (2020). Effect of transportation distances, seasons and crate microclimate on broiler chicken production losses. PLoS One. 15(4): 1-22. DOI: https://doi.org/10.1371/journal.pone.0232004

Seidavi A, Zaker-esteghamati $H$ and Scanes C (2019). Present and potential impacts of waste from poultry production on the environment. World's Poultry Science Journal. 75(1): 29-42. DOI: https://doi.org/10.1017/S0043933918000922

Indonesian National Standard (SNI) (2000). Maximum limit of microbial contamination and residue limit in foodstuffs of animal origin. SNI No: 01 - 6366 : 2000. National Standardization Agency of Indonesia, Jakarta. Article link: https://bpmsph.org/wpcontent/uploads/2016/06/SNI-01-6366-2000-Batas-maksimum-cemaran-mikroba-dan-batas-maksimum-residu-dalam-bahanmakanan-asal-h.pdf

Indonesian National Standard (SNI) (2009). Maximum limit of heavy metal contamination in food. SNI 7387; 2009. National Standardization Agency of Indonesia, Jakarta. Link: https://sertifikasibbia.com/upload/logam_berat.pdf

Indonesian National Standard (SNI) (2009). Maximum limit of microbial contamination in food. SNI 7388 ; 2009. National Standardization Agency of Indonesia, Jakarta. https://standarpangan.pom.go.id/dokumen/pedoman/Buku_Pedoman_PJAS_tentang_Cemaran.pdf

Stephenson AH, McCaskey TA and Ruffin BG (1990). A. survey of broiler litter composition and value as a nutrient resource. Biological Waste. 34(1): 1-9. DOI: https://doi.org/10.1016/0269-7483(90)90139-J

Sun P, Cabrera ML, Huang C and Pavlostathis SG (2014). Biodegradation of veterinary ionophore antibiotics in broiler litter and soil microcosms. Environmental Science Technology. 48(8): 2724-2731. DOI: https://doi.org/10.1021/es404619a

Uchimiya M, Bannon DI, Wartelle LH, Lima IM and Klasson KT (2012). Lead retention by broiler litter biochars in small arms range soil: impact of pyrolysis temperature. Journal Of Agricultural and Food Chemistry. 60(20): 5035-5044. DOI: https://doi.org/10.1021/jf300825n

Uchimiya M, Lima IM, Klasson KT, Chang S, Wartelle LH and Rodgers JE (2010). Immobilization of heavy metal ions (Cu", Cd", Ni", and Pb") by broiler litter-derived biochars in water and soil. Journal of Agriculture and Food Chemistry. 58(9): 5538-5544. D0I: https://doi.org/10.1021/jf9044217

Utama CS, Sulistiyanto B and Yolansa ABA (2019). Quality improvement of fermented wheat pollard with addition of vitamin minerals seen from potential hydrogen content, total lactic acid bacteria and total yeast. IOP Conference Series: Earth and Environmental Science. 518(2020): 1-6. Link: https://iopscience.iop.org/article/10.1088/1755-1315/518/1/012017

Vilchis Z, Williams SE and Johnson CN (2012). Environmental temperature affects prevalence of blood parasites of birds on an elevation gradient: implications for disease in a warming climate. Plos One. 7(6): 39208. DOI: https://doi.org/10.1371/journal.pone.0039208

Wang L, Lilburn M and Yu Z (2016). Intestinal microbiota of broiler chickens as affected by litter management regimens. Frontiers in Microbiology. 7: 593. DOI: https://doi.org/10.3389/fmicb.2016.00593

Wiedemann A, Virlogeux-Payant I, Chaussé AM, Schikora A and Velge P (2015). Interactions of salmonella with animal and plants. Frontiers in Microbiology. 5(791): 1-19. DOI: https://doi.org/10.3389/fmicb.2014.00791 